\title{
ГОСТИННІСТЬ ЯК БЕЗУМОВНИЙ ДАР: ДО ПОСТАНОВКИ ПРОБЛЕМИ
}

Розкривається зміст гостинності як безумовного дару, з'ясовується ї̈ місие серед інших форм комунікаџії. Виявляються функціональні аспекти явища, його ціннісна основа, обставини формування інституту гостинності безумовного дару в історичному контексті. Особлива увага приділяється розгляду гостинності як сакрального явища в контексті релігійних вчень.

Ключові слова: гостинність, безумовний дар, комунікація, дарообмін, потлач.

Раскрывается содержание гостеприимства как безусловного дара, выясняется ее место среди других форм коммуникации. Выявляются функииональные аспекты явления, его ценностная основа, обстоятельства формирования института гостеприимства безусловного дара в историческом контексте. Особое внимание уделяется рассмотрению гостеприимства как сакрального явления в контексте религиозных учений.

Ключевые слова: гостеприимство, безусловный дар, коммуникаџия, дарообмен, потлач.

The content of hospitality as an unconditional gift, it turns its place among other forms of communication. Identifies functional aspects of the phenomenon, its value basis, the circumstances of the formation of the institute of hospitality unconditional gift in a historical context. Particular attention is paid to the hospitality as a sacred phenomenon in the context of religious teachings.

Key words: hospitality, unconditional gift, communication, daroobmin, Potlatch.

Традиції гостинності виявляють найхарактерніші риси комунікативної культури народів світу. Гостинність завжди була не тільки обов' язковим компонентом способу життя, а й частиною світосприйняття, вірувань і повір’їв. Проблеми, які існують в сучасному світі і шляхи їх розв'язання потребують жертовності. У свою чергу гостинність, завдяки своїй властивості проникати у всі сфери життєдіяльності людини являється універсальною формою жертовності. Тому дослідження феномену гостинності та його складових є надзвичайно актуальним на сьогодні. Адже в умовах глобалізації саме гостинність може забезпечити не тільки оптимальні форми комунікацій між народами, але й зберегти при цьому їх національну ідентичність.

Об’ єктом дослідження є гостинність як одна із форм комунікативної культури народів світу.

Предметом дослідження є обставини формування інституту гостинності безумовного дару в історичному контексті. Автор з'ясовує місце гостинності як безумовного дару серед інших форм комунікації, виявляє функціональні аспекти цього явища та його ціннісну основу. 
У традиційній культурі феномен гостинності представляє собою високоритуалізоване дійство, певний морально-релігійний і соціально-правовий інститут. Гостювання, гостина розгортається у складний ритуал, витоки якого сягають доісторичних часів. Стародавній грек і германець, індіанець, африканець чи слов'янин, не намагалися вбити мандрівника, а навпаки зустрічали його як гостя. Часом, приймаюча сторона приготує все із останніх, взятих у борг або навіть вкрадених запасів наскільки можливо розкішний стіл, надасть на ніч зручне приміщення, поступиться хазяйською постіллю, а при від’ізді обдаровує подарунками, проводить до кордонів володінь громади і часто вважатиме образою для себе будь-яку пропозицію відплати. Такі риси гостинності характерні для багатьох народів світу і в наш час.

Поряд з гостинністю відповідного дарообміну існує гостинність безумовного дару. Такого роду гостинність зустрічається у всіх традиційних суспільствах. Суть ії полягає у тому, що вона передбачає надання дару як основного змісту гостинності без наміру отримати від гостя дарунку у відповідь, тобто здійснення нічим не обумовленого вчинку. Характерними рисами такої форми взаємодії є реалізація ідеї свободи через подолання зобов'язань, а також припинення двостороннього дарообміну як невідповідного дару, і, побудова нової моделі суспільних відносин. Концепція гостинності безумовного дару в нових соціально-економічних умовах передбачає певні соціальні дії, побудовані на стійкій, нічим не обмеженій мотивації людей до дії. Саме вони формують у суспільній комунікації найбільш стійкі форми доброзичливих стосунків, на що вказують теорії дарообміну. Ці стосунки складають значний потенціал для зародження нових більш ефективних і стійких моделей суспільної комунікації.

Закони, звичаї, традиції та літературні образи гостинності вивчаються в міждисциплінарному контексті з позицій антропології, філософії, семіотики, соціології, етнографії, історії, літературознавства, а також економіки, практичної політики, ідеології і права. Тема основ функціонування феномену гостинності в суспільстві піднімалася також в наукових пошуках, тісно пов’язаних з сервісною реальністю, туристичним бізнесом. Термін безумовний дар взагалі не поширений в літературі, але поняття безумовного дару має місце у таких авторів як Ж. Батай, Ж. Дерріда, С. Жижек, Е. Левінас та інші $[3 ; 6 ; 8 ; 14]$.

Науковцями, які здійснили вагомий внесок в розробку розуміння специфіки гостинності є Г. Андрущенко, А. Байбурін, М. Іваннікова, В. Латишев, Л. Лихачова, I. Пахолова, В. Русавська, І. Сухіна, та інші $[1 ; 2 ; 10 ; 12 ; 13 ; 15 ; 19 ; 20 ; 21]$. Слід виокремити важливість роботи фахівців з антропології М. Мосса, Л. Тевено, Є. Ярославського[16; 17; 23]. Значної уваги заслуговують класичні філософські праці I. Канта [11], лінгвістичні пошуки Е. Бенвеніста [4].

Мета статті - розкриття сутності феномену гостинності безумовного дару як первинної форми гостинності. Реалізація поставленої мети передбачає виконання наступних завдань:

- проаналізувати обставини формування інституту гостинності безумовного дару;

-виокремити історичні форми цього типу гостинності;

- розглянути мотивацію до двосторонньої взаємодії в умовах іiі реалізації.

У процесі історичного розвитку інститут гостинності зазнав безліч змін і за формою, і за змістом, але не втратив моральної основи. Феномен гостинності також, хоч і опосередковано зберігає відбитки релігійних вірувань попередніх епох. Як різновид 
соціальної діяльності гостинність складається навколо відносин, що виникають у процесі надання дарів і послуг подорожуючим. При цьому подорожуючий завжди виступає як споживач цих послуг, а стороною, що надає ці послуги, є суб' єкт, який перебуває в середовищі свого постійного існування [5]. Досліджуючи основи гостинності, Русавська В. А., доходить висновку, що вона є з'єднувальною ланкою між соціальними процесами і структурами, з одного боку, та культурою і духовним життям - 3 іншого [21]. Як свідчить етимологія, первинне значення терміну описує саме неприбуткову, стихійну, традиційну, обрядову сферу відносин.

Практично всі джерела, які стосуються визначення структурних складових гостинності, вказують на центральне місце дарообміну у відносинах учасників взаємодії. Обмін дарунками як комунікаційний засіб є особливо важливим явищем в процесі здійснення гостинності. Дарунок як матеріальний символ гостини в народній культурі відігравав значиму роль в культурах світу. Традиційно цінність дару полягала не стільки в самій речі, скільки у зв'язку, який встановлювався і підтримувався між дарувальником і отримувачем подарунку. Цей зв'язок встановлювався за ініціативою однієї із сторін, яка пропонувала іншій стороні дар. Альтернативний погляд на дарообмін у контексті здійснення гостинності представляє філософський підхід до чистого значення гостинності і її центральної категорії- дару. У такому контексті проводиться перегляд мети і мотивації моделей гостинної поведінки. У зв'язку з цим вводиться в обіг термін безумовного дару, який не передбачає отримання дару у відповідь, не потребує прагматичного встановлення ситуації боргу для сторони-реципієнта, що отримує подарунок. Основи гостинності за принципом безумовного дару змістовно описані в статті І. Пахолової «Гостинність без відплатного дару як соціокультурний досвід чужого». За визначенням автора, безумовний дар спрямований не на встановлення відносин обміну, а на припинення обміну і демонструє специфічні відносини з «чужим», з яким не виникає спільності, що дозволяє «чужому» залишатися «чужим» [19, с. 34]. Основна функція гостинності безумовного дару як ординарного досвіду «чужого» полягає в тому, щоб зберегти існуючий соціальний порядок і не допустити утворення нової спільності, встановлення відносин обміну. Особливість безумовного дару полягає в тому, що, як і будь-який дар, він припускає символічний обмін, але у випадку 3 безумовним даром справжнім предметом обміну є не розширення і зміцнення соціальних зв'язків, а припинення будь-якого обміну, запобігання утворення нової соціальної спільності [20, с. 12].

В історичному контексті гостинність безумовного дару постає одним із найдавніших інститутів, підкріплених звичаєвою формою життя. Існуючи поруч 3 традиційною гостинністю за формулою «потлача», характерною для первісних суспільств, в процесі змістовних трансформацій разом з іншими формами вона заклала фундамент сучасним формам гостинності народів світу. За своєю природою, інститут гостинності часто відігравав роль у формуванні добросусідських відносин всередині спільнот та у їх зовнішніх зв'язках. За сценарієм гостинності часто здійснювалося встановлення зв'язків племен і народів. Тому у минулому інститут гостинності наділявся привілейованим становищем - як неписаний закон, що визначає зобов'язання по відношенню до гостей-чужинців, священний обов'язок, недотримання якого підлягає 
божій і правовій помсті. Згодом гостинність перетворюється на соціальний інститут і наділяє обидві сторони союзу невід'ємними зобов' язаннями.

Ситуація гостинності часто засновується на тому сценарії, що одна людина вступає в зв'язок з іншими, беручи на себе зобов'язання відплатити за деяку послугу, яка їй була надана. Обмін дарами поділяють на типи за трьома обов'язками - обов'язком давати, приймати і відплачувати. 3 точки зору Дж. Болдуіна, соціальні відносини, мораль, емоційність, сім'я і гостинність створюються і підтримуються, можна сказати, діалогічним обміном дарами і послугами. На думку дослідника, позитивне значення цієї форми обміну в тому, що вона породжує «сімейні почуття», відданість, любов, великодушність і солідарність. Про це свідчать незліченні, повсякденні і безперестанні обміни - подарунками, послугами, допомогою, візитами, увагою, добротою [7, с. 94]. Іноді перевищити «іншого» в дарі, означає мати право очікувати в майбутньому дар ще більший. Це випробування щедрості і перемога в цьому випробуванні не матеріальна, а символічна. В той же час дар «іншому» є символічним вираженням влади, а дарувати, значить показувати свою силу, ставлячи «іншого» в підлегле і залежне становище.

Гостинність безумовного дару можна визначити як безумовну гостинність, що містить в собі вимогу надати прийом кожному, хто з'явиться на порозі дому. Тут найважливіший момент полягає в тому, що безумовний дарунок не служить причиною якихось зобов’ язань, не породжує новий порядок обміну. Якраз навпаки, безумовний дар припиняє обмін і тим самим заперечує соціальні відносини, засновані на обміні. На місце соціальних відносин обміну приходять вільні стосунки безумовного дару, які можуть мати непередбачувані наслідки і результати.

Звертаючись до історичного процесу розвитку різних світових цивілізацій, можна зробити висновок про паралельне існування обох форм гостинності - гостинності звичайного дарообміну і безвідплатної, що для цивілізаційного поступу мали велике значення. Звичай гостинності зародився ще в епоху первісного суспільства, а в період його розпаду набув особливої ваги як універсально поширений механізм подолання племінної замкнутості та налагодження міжплемінних контактів. Цей звичай був чи не єдиним засобом зміцнення та розвитку торгівлі та соціально-економічних зв'язків між територіально роз'єднаними народами. Гостинність в умовах родового суспільства виконувала функцію своєрідного міжнародного права. Найбільш стародавня форма гостинності обумовлена обміном дарами, тому союз гостинності, заснований i підкріплюваний взаємними дарами, гарантував недоторканність і безпеку на «чужій» території. Як вказує Е. Бенвеніст, йдеться про систему, характерну для індіанських племен північного заходу Америки, яка полягає в послідовності дарувань і відповідних дарувань, коли отримавши подарунок, партнер повинен в силу якогось зобов'язання неодмінно віддячити дарувальника більш цінним подарунком [4, с. 78]. Французький антрополог і релігієзнавець М. Мосс у «Ессе про дар» вказує, що в архаїчних суспільствах не ринкова торгівля, але саме колективний або персональний обмін дарами зумовлював багато важливих сторони економічного життя, більше того, він виходив за рамки перерозподілу матеріальних ресурсів і функціонував як обмін знаками уваги, бенкетами, обрядами, військовими послугами, жінками, дітьми, святами та іншими цінностями. Обмін дарами, пише він, конституював встановлення і закріплення 
договірних відносин між колективами або індивідами, накладав на них взаємні зобов’ язання [17]. За висновком Е. Бенвеніста, даний інститут під назвою «потлач» допомагає пояснити феномен гостинності, який є ослабленою формою першого.

З точки зору соціальної комунікації, традиційна гостинність дарообміну висуває ряд вимог до учасників взаємодії. Оскільки в даруванні необхідно беруть участь дві волі, їх прийняття означає добровільне визнання певних обов'язків однієї сторони гостини до іншої Для того, щоб дарування здійснилося, воля приймаючої та даруючої сторони має бути спільною. У даруванні передбачається взаємна угода, без якої факт дару не буде мати місця. Більше того, відповідно «загальної теорії зобов’ язань потлача», постає механізм взаємодії трьох видів соціальних обов'язків - давати дари, приймати дари і відшкодовувати дари. При цьому відмова від будь-якої складової тотожна оголошенню війни, оскільки розцінюється як знак відмови від «союзу та об'єднання», фактор соціальної дезінтеграції. У цьому складному механізмі дарувань, у примусовому порядку зобов'язують до дій у відповідь даруванням. Коли ця система компенсацій діє в межах одного і того ж кола людей, вона призводить до виникнення спільноти людей, об'єднаних взаємними зобов'язаннями.

У лінгвістичних дослідженнях феномену гостинності Е. Бенвеніст доходить висновку, що не можна не визнати, що поряд з гостинністю, призначеною для взаємної відплати, існувала і гостинність безумовного дару. За даними, приведеними дослідником, існує два терміни gratus munus - це дарування, яке зобов' язує до повторного дарування, i immunis ставиться до того, хто не виконує цього обов’ язку. Сказане підтверджує що існує модель взаємодії, яка не вимагає в своїй мотивації і змісті розділяти проаналізовані вище обов'язки з іншими. Етимологічна передісторія вказує однозначно на такий дар, який не передбачає відповідного дарування і недвозначно свідчить про те, що паралельно існує також і саме безкорисливий дар [17, с. 80].

Дійсно, безумовний дар не вимагає виплати за векселями, ні до чого не зобов’язує тих, на кого він спрямований і заради кого зроблений. Безумовний дар завжди створює територію свободи для суб'єкта дії у своєму дарі, а отримувач вільний у тому, щоб прийняти або відкинути дар, а також не відповісти на дар своїм даром [19, с. 34]. Він здійснюється за принципом - даруй себе, i не чекай i, тим більше, не вимагай нічого натомість. За великим рахунком, дія безумовного дару не скасовується навіть тоді, коли на дар отримана відповідь - адже відповідь була необов'язковою і багато в чому випадковою. За своїм визначенням безумовний дар гостинності передбачає те, що ніхто нікому не зобов'язаний, не повинен вести себе за правилами і дотримуватися встановленого кордону. Безумовний дар відкриває свободу поза традиційних прагматичних відносин, взаємодії без умов, ризикованої і непередбачуваної, що виходить за рамки вже існуючого соціального порядку. Головне призначення безумовного дару - забезпечити неможливість встановлення відносин обміну, прагматики і покласти початок зародженню нових соціальних зв'язків. Дію за зразком безумовного дару можна вважати успішною тоді, коли в результаті залишається незмінним колишній порядок соціальних відносин.

Основна функціями гостинності безумовного дару полягає в тому, щоб зберегти існуючий соціальний порядок, або порядок відносин, порядок утворення смислів, 
властивий для того чи іншого співтовариства і не допустити утворення нової спільності через встановлення відносин обміну. Справжнім предметом обміну в гостинності безумовного дару є недопущення самої можливості будь-якого символічного обміну між сторонами.

Однією з найважливіших мотивацій складного й багатофункціонального ритуалу гостинності безумовного дару є спільне для багатьох народів архетипне уявлення про сакральність гостя. Це є одна із засад пояснення походження інституту безумовного дару - релігійна. Міфологічна основа гостя й гостинності втілена в багатьох звичаях, обрядах та народних піснях. Інший дієвим стимулом дотримуватися законів гостинності в період великих цивілізацій був страх перед гнівом і покаранням богів, де кара, яка очікує клятвопорушників, сприймалася як реальність. За визначенням В. Русавської, гостинність розглядається як повсякденна і святкова, а також як селянська, громадська, міська, родинна, дворянська, світська і церковно-монастирська [21, с .28]. В цілому поділяючи запропоновану класифікацію, можна виокремити релігійну основу гостинності. Це пояснюється тим, що на відміну від світської гостинності, у якій «ритуал приймання гостя перетворюється на формальну процедуру», релігійна гостинність грунтується, зокрема в християнстві, на заповідях і наповнена важливим духовним змістом, зокрема, співчуття і допомоги ближньому.

Яскравим прикладом реалізації концепту безумовного дару гостинності є традиції приймання жебраків, описані у праці Е. Ярославського «Жебраки завжди бажані гості у домі християн» [23]. Автор зазначає, що жебраки у селянському середовищі Бретані і Росії входили в ту категорію людей, з якими неможливо було встановити відносини обміну під час здійснення гостинності, адже жебрак - це не той, хто дає, а той, кому дають, на кого поширюється дія безумовного дару. Жебрак міг з'явитися на порозі будинку в будь-який момент і розраховувати на особливе ставлення до себе. На жебраків були спрямовані різні благодіяння: їх обдаровували милостинею, влаштовували на нічліг в будинку, вони були непроханими, але бажаними гостями на сімейних святах. Ставлення до жебраків в давнину визначалося древнім повір'ям, що існувало в усній традиції, яке зводилося до наступного: «Жебраки є гості Бога. Ніколи не почують вони грубе слово на порозі селянського будинку, тому і не зупиняються в нерішучості біля дверей, а сміливо заходять» [23]. Важливі ідеї, що містяться в легендах народного фольклору щодо надання гостинності, говорять про те, що Бог винагороджує гостинних, i що гостинність має надаватися від чистого серця. Звертання до даного матеріалу є цікавим 3 тієї причини, що тут гостинність за принципом безумовного дару розкривається саме як повсякденний, а не винятковий соціокультурний досвід.

Одним із дієвих стимулів щодо дотримання принципу безумовного дару є діяння святих і релігійних постатей у християнстві. 3 такою літургійною дією пов’ язують вчинки в історії Мойсея у Старому Заповіті. Мойсей, як відомо, по своїй волі, свідомо приймає на себе місію пророка, покликаного вивести єврейський народ з Сгипту в Землю Обітовану. При цьому він знає, що сам не досягне мети, не ступить на землю, обіцяну його народу, не зможе скористатися плодами своєї праці, нічого не отримає натомість своїх зусиль. Мойсей робить жест безумовного дару, вкладаючи всього себе в майбутнє інших людей, але не в своє. Подібно Мойсею Еней у творі Вергілія також присвячує 
себе і все своє життя не своєму майбутньому, а майбутньому інших поколінь. Еней виводить троянців, яким загрожує полонення і рабство, з Трої, щоб привести їх у землю, обіцяну богами - майбутній Рим.

Можна сказати, що чистим жестом безумовного дару в християнській культурі $\epsilon$ жертвоприношення Христа. На думку науковців, християнська етика загалом заснована на ідеї переривання обміну, руйнуванні логосу справедливості, який за злочин вимагає покарання, відшкодування збитків. Заклик Христа підставити щоку розмикає круговий ланцюг провини і відплати, усуває з соціальних відносин принцип обміну і стверджує принцип безумовного дару. Таким чином, і жертва Христа-це його дар, який не підлягає обміну, його не можна перевищити.

Відповідно до аналізу ряду релігійних вчень, експерти висувають припущення, що у релігії вищими субстанціями переважно не заохочується надлишкове багатство одних людей і крайня бідність інших, тому для багатих щедрість є обов'язковою: дарувати частину свого майна у формі милостині - моральний імператив багатих. Так «вимальовується теорія милостині» та етики багатства [17, с. 67]. Надання гостинності, прийом і допомогу мандрівникам відігравали значну роль у житті ранніх християн [18]. Це підтверджують і повторювані вмовляння і нагадування, на зразок тих, що ми знаходимо в апостольських посланнях: «Будьте гостинні один до одного без нарікання» або: «Не забувайте, бо через нього деякі надавали гостинність ангелам». Ці заклики викликані, мабуть, двома причинами:

-по-перше - практичної потребою, оскільки хазяї, безперечно, надавали подорожуючим значну допомогу, що встановлювало тісні доброзичливі міжнародні зв'язки;

- по-друге-етичними міркуваннями.

Таким чином, на прикладі розгляду релігійних мотивів безумовного дару, можна бачити, як уже на такому ранньому етапі свого розвитку, християнське вчення в повній мірі виявляло тенденцію до етики безвідплатних вчинків.

Теоретичним підгрунтям для дослідження поняття гостинності в філософії є праці I. Канта [11]. Поглиблення його ідей знаходимо в наукових розвідках Ж. Дерріди, Е. Левінаса [6; 14]. Згідно з І. Кантом, проблема гостинності полягає в можливості чужоземця відвідувати територію іншої держави і при цьому не ставати її ворогом. I. Кант у праці «Основи метафізики моральності» обстоює моделі двосторонньої взаємодії в умовах здійснення морального вчинку щодо Іншого [11]. За дотримання першої, або адекватної схеми взаємодії, суб'єкт дарунку, або дії не має наміру отримати взамін щось від Іншого за дану інтеракцію, і останній це також розуміє і тому не $\epsilon$ зобов’ язаним до дії віддачі. За іншої схеми, або за єдиним неправильним варіантом взаємодії, реципієнт дарунку вдається до лихого вчинку стосовно Іншого. Як висновок - обидва учасники дарообміну є абсолютно незалежними, як до, так і після вчинення діï, i можуть діяти як завгодно, не маючи жодних зобов’ язань окрім як завдавати шкоди один одному.

Однією з перших спроб осмислити дар як діяння, яке не потребує відповіді, $є$ етична феноменологія Е. Левінаса. Він говорить про особливі дії, які вимагають етичного ставлення, і ці дії є літургією, тобто діяннями невигідними і нерозділеними 
витратами на користь Іншого. У Е. Левінаса літургія постає як безмовний дар, зроблений на користь майбутніх поколінь, в якому себе проявляє «буття-по-той-бік-смерті» [14].

Ж. Дерріда пропонує розглядати гостинність як загальний безумовний закон або кантівський категоричний імператив. Французький філософ ставить знак рівності між гостинністю і етикою - етичне ставлення і $є$ гостинністю. До ідеї безумовного дару Ж. Дерріда звертається у своїй роботі «Дарувати смерть» і не бачить семантичного сенсу в тому, щоб відокремлювати поняття безумовного дару як різновиду дару. Він пропонує переглянути те розуміння дару, яке склалося в соціокультурному знанні завдяки дослідженням М. Мосса щодо відносин прагматичного товарообміну. Дар потрібно мислити, на думку філософа, в його «чистій» формі: поза економікою, поза обміном, поза відповідним даром. Дерріда виводить формулу: «Якщо Інший віддав або заборгував мені те, що я йому подарував, це означає, що потрібно віддавати назад, $\mathrm{i}$ що ніякого дару немає. Це цілком зрозуміло, якщо Інший, отримавши дар, віддає мені безпосередньо те ж саме» [6]. Тут мова йде про дар в його абсолютному значенні, в його етичному розрізі: якщо дар можливий, то можливий тільки як безумовних дар.

У суспільствознавстві вважається, що звичайна гостинність відплатного дару, розширює життєвий простір суспільства, підтримує економіку обміну між різними спільнотами. Під гостинністю розуміється ритуал соціального визнання, який характеризується певними випробуваннями, i, як результат, включенням У нове суспільство і закріпленням за індивідом нового соціального статусу. Специфіка ритуалу соціального визнання в традиційному суспільстві полягає в тому, що він служить умовою, за допомогою якої емоції швидше контролюються і приховуються, ніж виражаються. Іншими словами, в сучасних умовах ритуал соціального визнання прийняв різновид правил етикету [22, с. 54]. Проте дії за зразком безумовного дару можуть змінити існуючий порядок речей, зруйнувати попередні соціальні зв'язки, також і наслідування безумовного дару здатне перешкодити утворенню нових відносин, нової спільності. У той час як дія відповідного дару здійснює відносини обміну, тим самим зміцнюючи і розширюючи суспільні зв'язки, дія безумовного дару, навпаки, заперечує саму можливість виникнення будь-яких соціальних зобов'язань.

За своєю природою цей обмін був якісно відмінний від товарообміну. Разом 3 тим, сутнісною особливістю гостинності безумовного дару є те, що це сфера вільних, ризикованих, непередбачуваних і випадкових відносин. Тому сама по собі гостинність безумовного дару не гарантує уникнення невдач у комунікації. Тим не менше, суттєвою перевагою гостинності безумовного дару є те, що це конкретна можливість «чужого» заявити про себе як про «чужого» - тут ми маємо справу з готовим «місцем» для «чужого» в соціокультурному просторі. У гостинності безумовного дару «чуже» вже очікуване в сценарії несподіваної зустрічі, яка забезпечена звичним порядком дії по відношенню до «чужого». Чистий концепт дару передбачає становлення комунікації без покладання зобов'язань у разі прийняття дару однією зі сторін, i таким чином, $\epsilon$ однією з форм прояву ліберального способу організації буття.

Таким чином, гостинність безумовного дару не обмежується соціокультурним досвідом традиційних суспільств, а є цілком прийнятною моделлю взаємодії і для сучасної культури. Можна зробити висновок, що гостинність безумовного дару $є$ 
актуальною формою комунікації, історично заснованої в минулому. Вона успішно функціонувала в процесі історичного розвитку поряд з гостинністю відплатною, заснованою на компенсаційному товарообміні. Виконуючи різні функції, обидві форми становлять неподільну єдність і постають як соціальний інститут гостинності.

Перспективи подальших досліджень передбачають розкриття змісту широкого кола питань, зокрема визначення функцій гостинності безумовного дару, його складових, моделей поведінки і цивілізаційної ролі в процесі еволюції різних форм комунікації. 3 огляду на іiї актуальність для сьогодення, гостинність безумовного дару може стати складовою етичних досліджень у філософському дискурсі. Подальші наукові розвідки варто спрямувати на глибоке вивчення міжкультурних взаємовідносин між історичними i сучасними спільнотами у розрізі питання гостинності, перевіряючи іiі форми на співпадання з сценарієм мотивацій щодо гостинності безумовного дару.

\section{Лimepamypa:}

1. Андрущенко Г. І. Гостинність як одна із перших форм прояву людської довіри / Г. І. Андрущенко // Соціальні технології, 2011. - № 52. - С. 7-12. 2. Байбурин А. К. У истоков этикета : этнографические очерки / А. К. Байбурин, А. Л. ; Акад. наук СССР. Ленинград : Наука, 1990. - 168 с. 3. Батай Ж. Теория религии. Литература и Зло / Ж. Батай; пер. с фр. Ж. Гайковой, Г. Михалковича. - Минск : Современныий литератор, 2000. - 352 с. 4. Бенвенист Э. Словарь индоевропейских соииальных терминов / И. Бенвенист ; пер. с фр. общ. ред. и вступ. статья Ю. С. Степанова. -Москва : ПрогрессУниверс, 1995. - 456 с. 5. Вишневська Г. Г. Еволючія сфери гостинності міста Києва другої половини XIX - початку XX століття в контексті розвитку українського туризму : автореф. дис... канд. культурології: 26.00.06 / Г. Г. Вишневська ; Київ. наи. ун-т культури і мистеитв. - Київ, 2008. - 19 с. 6. Дерріда Ж. Дарувати час / Ж. Дерріда ; пер. $з$ фр. М. Ющенко. - Львів : Літопис, 2008. - 204 с. 7. Джон Болдуин. «Жизни нужна страсть»: Бодрийяр и дар / Дж. Болдуин // Хора. -2009, № 2 (8). - С.89-108. 8. Жижек С. Возвышенный объект идеологии / С. Жижек ; пер.с англ. В. Софронов. - Москва : Худож. журн., 1999. 236 с. 9. Жорж Батай. Проклятая часть : сакральная соичология / Ж. Батай. - Москва : Ладомир, 2006. - 742 с. 10. Іваннікова М. Етнопедагогічні традииї, їх зміст, структура, функиї / М. Іваннікова // Вісн. ін-ту розвитку дитини : зб. наук. пр. - Київ, 2012. - Вип.23. С. 79-84. 11. Кант И. Основы метафизики нравственности / И. Кант. - Москва: Изд-во «Мысль», 1965. - 1471 с. 12. Латышев В. В. Очерк греческих древностей. Богослужебные и сиенические древности / В. В. Латышев. - Санкт-Петербург : Алетейя, 1997. - 319 с. 13. Латыпев В. В. Государственные и военные древности : очерк греческих древностей. / В. В. Латышев ; вступ. статья и общ. ред. Э. Д. Фролов. - Санкт-Петербург : Алетейя, 1997. - 347 с. 14. Левинас Э. Избранное : тотальность и бесконечное / Э. Левинас ; пер. И. С. Вдовина [и др.] ; сост. С. Я. Левит. - Москва : Культ. Инициатива ; СанктПетербург : Университетская кн., 2000. - 415 с. 15. Лихачева Л. Этикет в социальном взаимодействии : полипарадигмальныий подход / Л. Лихачева. - Екатеринбург, 2000. 153 с. 16. Лоран Тевено. Чудесный хлеб гостеприимства : (недоразумения, проясняющие открытость и закрытость сообществ) / Л. Тевено, Н. Карева. // Новое литературное обозрение. 2009. № 6 (100). С. 678-701. 17. Мосс М. Очерк о даре. Форма и основание обменах в архаических обществах / М. Мосс // Общества. Обмен. Личность : труды по сочиальной антропологии / Пер. с франи., послесловие и коммент. А. Б. Гофмана. - Москва : Восточная литература, РАН 1996.18. Мязина.О. Б. Страннолюбие в раннехристианских 
общинах и античный обычай гостеприимства // Закон и обычай гостеприимства в античном мире : доклады конф. - Москва, 1999. - Ч.2. - С. 177-180. 19. Пахолова И. В. Гостеприимство безответного дара как соииокультурньй опыт «Чужсого» / И. В. Пахолова // Междунар. журн. исследований культуры. - Санкт-петербург, 2011. - №1. - С. 32-38. 20. Пахолова И. В. Социокультурный образ «Чужого» // Автореф. дис... на соискание ученой степени канд. филос. наук : 09.00.11 / Пахолова Ирина Викторовна ; Сам. гос. ун-т. Самара, 2010. - 20 с. 21. Русавська В. А. Гостинність в духовній культурі украӥнського суспільства / В. А. Русавська // Духовна культура як домінанта украӥнського життєтворення : зб.матеріалів Всеукр. наук.-практ. конф. -Київ, 2005. 22. Хамрина Ю. B. Способы и пути трансформации ритуалов в современном обществе / Ю Хамрина // Вестн. Томского государственного ун-та. - Томск, 2011. - С. 53-56. 23. Ярославский Е. Нищие всегда ожидаемы в доме крестьянина (Традиџии гостеприимства в Бретани и в России в XIX в.) // Традиционные и современные модели гостеприимства : материальь российско-франиузской конф. 7-8 окт. 2002 г. / под ред. С. Н. Зенкина, А. Монтадона. Москва : Изд-во РГГУ, 2004. -. С. 27-54. 